\title{
Impact of the Fine-Tuning Medium-of-Instruction Policy on Learning: Some Preliminary Findings
}

\author{
Anita Y. K. Poon, Connie M.Y. Lau, Dennis H.W. Chu \\ Hong Kong Baptist University
}

\begin{abstract}
After twelve years' implementation in junior secondary schools in Hong Kong, the compulsory Chinese medium instruction policy was replaced by the fine-tuning medium of instruction policy in September 2010. The greatest criticism of the compulsory Chinese medium instruction policy is its adverse effect on students' English standards, which have been declining. The fine-tuning medium of instruction policy is an innovative idea that provides a break-through from the traditional mode of English-medium schools vs Chinese-medium schools and thus brings a close to the age-long debate on the heated topic of medium of instruction in Hong Kong. The new policy permits schools to have flexibility to offer English-medium classes, partial-Englishmedium classes and/or Chinese-medium classes provided that certain criteria are met. The present study investigates the fine-tuning medium of instruction policy in its initial stage of implementation and finds out the impact of this new language policy on learning. A quantitative research method - survey - is employed to collect data pertaining to the views of students on the impact of the fine-tuning medium-of-instruction policy on learning.
\end{abstract}

\section{Introduction}

Medium of instruction (MOI) has long been a heated issue in Hong Kong. Whether to use Chinese or English as a medium of teaching and learning has been debated over the past five decades [17]. It is legitimate to use L1 (i.e. Chinese) as the MOI at school as $95 \%$ of the population is ethnic Chinese (Census and Statistics Department, 2011). However, English-medium instruction (EMI) rather than Chinese-medium instruction (CMI) is a preferred choice of students, parents and schools. The reasons are three-fold: (1) Historically Hong Kong was a British colony and "superposed bilingualism" [18] and the subsequent use of EMI at school was a feature of the language situation in Hong Kong; (2) the status of Hong Kong changed from a manufacturing hub in the 1960 s to an international city of trade and finance in the 1980s, and then to an international financial centre since the 1990s, so there is a high demand for English in Hong Kong society; (3) good English is a prerequisite for entering universities in Hong Kong, which are English-medium, and a university graduate stands a much higher chance of finding a high-pay job.

To date there have been four MOI policies, namely the laissez-faire MOI policy prior to 1994 , the streaming policy during 1994-1998, the compulsory Chinese medium-of-instruction policy during 1998-2010, and the fine-tuning medium-ofinstruction policy since September 2010. Under the laissez-faire MOI policy the majority of secondary schools claimed to be EMI schools, many of which actually used mixed code (i.e. mixing Chinese words in English sentences) in the classroom. The streaming policy aimed to resolve the problem of using mixed code in teaching by streaming schools into EMI schools, CMI schools and two-medium schools [4]. It was suddenly replaced by the compulsory Chinese medium-of-instruction policy because of the handover of Hong Kong to the People's Republic of China. The greatest criticism of the compulsory Chinese medium-of-instruction policy is the declining English standards and students' lack of motivation to learn English [17], [25]. The recent fine-tuning medium-of-instruction policy is meant to remedy the situation.

Under the new MOI policy secondary schools in Hong Kong are permitted to offer EMI classes, partial-English-medium classes (i.e. one to two subjects taught in English), and/or CMI classes. The eligibility of launching EMI classes is based on the Secondary 1 (S1) allocation results of schools in the previous two years prior to 2010. Schools are eligible to offer one EMI class with all subjects taught in English except Chinese and Chinese History if $85 \%$ of their S1 student intake of that class (e.g. 34 students out of 40 in a class) belongs to the 'top 40\%' group according to the government's S1 allocation results. As for the classes that do not meet this requirement, schools have the following options: (1) teach all subjects except English Language subject through the medium of Chinese; (2) make use of a maximum of $25 \%$ of the entire curriculum time, which is originally designated to Extended Learning Activities (ELA) to enhance students' English, to teach up to 2 content-based subjects through the medium of English; (3) make use of the time for 
ELA to teach 1 content-based subject through the medium of English plus some other content-based subjects incorporating several units taught in English; (4) make use of the time for ELA to teach some units of some content-based subjects in English. Hence there are different arrangements for MOI under the new policy.

The present paper reports on some preliminary findings of a study that investigated the impact of different MOI arrangements on learning, focusing primarily on EMI classes and partial-EMI classes, in the first year of implementation of the fine-tuning medium-of-instruction policy.

\section{Research methodology}

The following are the research questions of the study:

1. What are students' attitudes towards the changing MOI?

2. How does the changing MOI affect learning in the classroom generally and how does EMI affect students' learning specifically?

3. Will the fine-tuning MOI policy enhance students' English proficiency?

4. What are the factors affecting students' MOI preference?

A quantitative research method - survey - is employed to collect data pertaining to the views of students on the impact of the fine-tuning medium-ofinstruction policy on learning.

A sample of 461 students with 223 girls, 231 boys and 7 unidentified from three schools was surveyed. The participants aged 11-15 years old were studying in S1 in 2010 when the fine-tuning MOI policy was first implemented.

The questionnaire consists of 7 parts and there are altogether 63 statements. A 4-point Likert scale is used in all statements with '4' as 'strongly agree' and ' 1 ' as 'strongly disagree'. 'NA' refers to 'not applicable', which means zero relevancy in responding to the statements provided.

Statistical analysis was run on the survey data using SPSS. The following procedures were performed:

- Descriptive statistics

- Pearson's factor analysis

- t-test

- Multiple regression analysis

\section{Results and findings}

To examine the factor structure of the questionnaire items, exploratory factor analysis (EFA) was conducted using IBM SPSS 19. Six factors were identified and categorised as English Proficiency, MOI Effect on Learning, EMI Effect on
Students, Student Attitudes, Factors Affecting MOI Choice, and Impact of MOI Policy on Schools. The last factor is excluded from our discussion as it is not the concern of this paper.

Table 1. Factor analysis

\begin{tabular}{|c|c|}
\hline Factors & Sub-factors \\
\hline $\begin{array}{l}\text { English } \\
\text { Proficiency } \\
(E P)\end{array}$ & No sub-factor \\
\hline $\begin{array}{l}\text { MOI effects on } \\
\text { learning } \\
\left(M O I \_L\right)\end{array}$ & $\begin{array}{ll}\text { - } & \text { LL_F1 (mixed code) } \\
\text { - } & \text { LL_F2 (difficulties) } \\
\text { - } & \text { LL_F3 (strategies) }\end{array}$ \\
\hline $\begin{array}{l}\text { EMI effects on } \\
\text { students } \\
\text { (EMI_S) }\end{array}$ & $\begin{array}{ll}\text { - } & \text { SL_F1 } \\
\text { learning) } & \text { (enhance } \\
\text { - } & \text { SL_F2 (improve } \\
& \text { academic resutls) }\end{array}$ \\
\hline $\begin{array}{l}\text { Students' } \\
\text { attitudes } \\
\text { (SA) }\end{array}$ & $\begin{array}{ll}\text { - } & \text { ATT_F1 (positive } \\
\text { attitudes) } \\
\text { - } \\
\text { ATT_F2 (sense of } \\
\text { superiority) }\end{array}$ \\
\hline $\begin{array}{l}\text { Factors } \\
\text { affecting MOI } \\
\text { choice } \\
\text { (MOI_choice) }\end{array}$ & $\begin{array}{ll}\text { - } & \text { Factor_1 (Others' } \\
\text { suggestions) } \\
\text { - } & \text { Factor_2 (future study } \\
\text { and job requirement) } \\
\text { - } & \text { Factor_3 (Possibility to } \\
\text { achieve higher grades) } \\
\text { - } & \text { Factor_4 (academic } \\
\text { ability and results) } \\
\text { - Factor_5 (Government } \\
\text { policy) }\end{array}$ \\
\hline $\begin{array}{l}\text { Impact of MOI } \\
\text { policy on schools } \\
\text { (MOI_impact) }\end{array}$ & $\begin{array}{l}\text { - EFF_1 (flexibility to } \\
\text { promote English) } \\
\text { - EFF_2 (special } \\
\text { arrangements) }\end{array}$ \\
\hline
\end{tabular}

The Cronbach's Alphas of these factors range from 0.54 to 0.89 , indicating that they have high internal consistency. The factorization results $(\mathrm{KMO}=.83$, Bartlett's test $=1092.84, \mathrm{df}=36, \mathrm{p}<.001)$ show that students were generally positive about English-medium instruction.

Tables 2a-2e below present some descriptive statistics. More than $70 \%$ of the students generally agreed that EMI helped to enhance English proficiency. 
Table 2a. Enhancement in English Proficiency

\begin{tabular}{|c|c|c|c|c|c|}
\hline & & $\begin{array}{c}\text { Strongly } \\
\text { agree }\end{array}$ & Agree & Disagree & $\begin{array}{l}\text { Strongly } \\
\text { disagree }\end{array}$ \\
\hline 1 & $\begin{array}{l}\text { I support the Fine- } \\
\text { tuning MOI policy } \\
\text { because I can choose } \\
\text { the medium of } \\
\text { instruction for my } \\
\text { learning. }\end{array}$ & $15 \%$ & $58 \%$ & $17 \%$ & $10 \%$ \\
\hline 2 & $\begin{array}{l}\text { Fine-tuning MOI } \\
\text { policy allows more } \\
\text { exposure to English. }\end{array}$ & $23 \%$ & $61 \%$ & $13 \%$ & $3 \%$ \\
\hline 3 & $\begin{array}{l}\text { With English as the } \\
\text { medium of } \\
\text { instruction, I have } \\
\text { opportunities to learn } \\
\text { content-based subject } \\
\text { knowledge in English. }\end{array}$ & $23 \%$ & $59 \%$ & $14 \%$ & $4 \%$ \\
\hline 4 & $\begin{array}{l}\text { With English as the } \\
\text { medium of } \\
\text { instruction, it helps } \\
\text { enhance my overall } \\
\text { English proficiency. }\end{array}$ & $24 \%$ & $46 \%$ & $22 \%$ & $8 \%$ \\
\hline
\end{tabular}

More than $70 \%$ of the students found it difficult to handle the teacher's questions and the vocabulary affected their understanding of subject knowledge. More than $50 \%$ of the students could understand only $50 \%$ of the subject content and found it difficult to take notes. More than $78 \%$ of students welcomed the use of mixed-code, which helped to enhance learning in lessons.

More than $70 \%$ of students agreed that EMI created more difficulties in learning, and might affect their academic results, but it helped learning in senior forms.

More than $80 \%$ of students generally preferred using Chinese as the MOI for better understanding the lessons; $46 \%$ of students agreed that students in EMI classes were superior to those in partial-EMI classes, but $54 \%$ disagreed with this.

$87 \%$ of students mainly considered their academic results and language ability when choosing MOI. About $70-80 \%$ of students admitted that they chose EMI because of university admission requirement and future job opportunities.
Table 2b. Effects of MOI on Learning

\begin{tabular}{|c|c|c|c|c|c|}
\hline & & $\begin{array}{c}\text { Strongly } \\
\text { agree }\end{array}$ & Agree & Disagree & $\begin{array}{l}\text { Strongly } \\
\text { disagree }\end{array}$ \\
\hline 1 & $\begin{array}{l}\text { With English as the } \\
\text { medium of instruction, } \\
\text { I need to prepare the } \\
\text { content before } \\
\text { attending lessons. }\end{array}$ & $16 \%$ & $58 \%$ & $20 \%$ & $6 \%$ \\
\hline 2 & $\begin{array}{l}\text { With English as the } \\
\text { medium of instruction, } \\
\text { I need to employ } \\
\text { specific strategies. }\end{array}$ & $18 \%$ & $64 \%$ & $12 \%$ & $6 \%$ \\
\hline 3 & $\begin{array}{l}\text { With Chinese as the } \\
\text { medium of instruction, } \\
\text { I am more confident in } \\
\text { handling questions } \\
\text { from teachers. }\end{array}$ & $60 \%$ & $31 \%$ & $7 \%$ & $2 \%$ \\
\hline 4 & $\begin{array}{l}\text { With Chinese as the } \\
\text { medium of instruction, } \\
\text { I can answer questions } \\
\text { more precisely. }\end{array}$ & $55 \%$ & $33 \%$ & $10 \%$ & $2 \%$ \\
\hline 5 & $\begin{array}{l}\text { With English as the } \\
\text { medium of } \\
\text { instruction, I find it } \\
\text { difficult to handle } \\
\text { questions from } \\
\text { teachers. }\end{array}$ & $28 \%$ & $36 \%$ & $30 \%$ & $6 \%$ \\
\hline 6 & $\begin{array}{l}\text { With English as the } \\
\text { medium of } \\
\text { instruction, I can only } \\
\text { understand } 50 \% \text { of the } \\
\text { content. }\end{array}$ & $20 \%$ & $33 \%$ & $37 \%$ & $10 \%$ \\
\hline 7 & $\begin{array}{l}\text { With English as the } \\
\text { medium of instruction, } \\
\text { vocabulary affects my } \\
\text { understanding of } \\
\text { subject knowledge. }\end{array}$ & $37 \%$ & $41 \%$ & $18 \%$ & $4 \%$ \\
\hline 8 & $\begin{array}{l}\text { With English as the } \\
\text { medium of instruction, } \\
\text { I find it difficult to take } \\
\text { notes. }\end{array}$ & $24 \%$ & $27 \%$ & $34 \%$ & $15 \%$ \\
\hline 9 & $\begin{array}{l}\text { With English as the } \\
\text { medium of } \\
\text { instruction, teachers } \\
\text { need to use mixed-code } \\
\text { to assist me to learn the } \\
\text { subject knowledge. }\end{array}$ & $40 \%$ & $43 \%$ & $13 \%$ & $4 \%$ \\
\hline 10 & $\begin{array}{l}\text { With English as the } \\
\text { medium of instruction, } \\
\text { teachers need to use } \\
\text { mixed-code to speed up } \\
\text { my learning. }\end{array}$ & $32 \%$ & $46 \%$ & $17 \%$ & $5 \%$ \\
\hline 11 & $\begin{array}{l}\text { With English as the } \\
\text { medium of instruction, } \\
\text { teachers need to use } \\
\text { mixed-code to facilitate } \\
\text { interaction and } \\
\text { communication for } \\
\text { learning. }\end{array}$ & $35 \%$ & $44 \%$ & $17 \%$ & $4 \%$ \\
\hline
\end{tabular}


Table 2c. Effects of EMI on Students

\begin{tabular}{|c|c|c|c|c|c|}
\hline & & $\begin{array}{c}\text { Strongly } \\
\text { agree }\end{array}$ & Agree & Disagree & $\begin{array}{l}\text { Strongly } \\
\text { disagree }\end{array}$ \\
\hline 1 & $\begin{array}{l}\text { With English as the } \\
\text { medium of instruction, } \\
\text { I am facing a large } \\
\text { amount of vocabulary, } \\
\text { which creates } \\
\text { difficulty in learning. }\end{array}$ & $34 \%$ & $37 \%$ & $25 \%$ & $4 \%$ \\
\hline 2 & $\begin{array}{l}\text { With English as the } \\
\text { medium of } \\
\text { instruction, I am } \\
\text { facing a large number } \\
\text { of complicated } \\
\text { sentences, which } \\
\text { create obstacles in } \\
\text { understanding the } \\
\text { content of the subject. }\end{array}$ & $30 \%$ & $40 \%$ & $26 \%$ & $4 \%$ \\
\hline 3 & $\begin{array}{l}\text { With Chinese as the } \\
\text { medium of instruction, } \\
\text { I can pick up content- } \\
\text { based subject } \\
\text { knowledge better, } \\
\text { faster and more } \\
\text { efficiently. }\end{array}$ & $48 \%$ & $38 \%$ & $11 \%$ & $3 \%$ \\
\hline 4 & 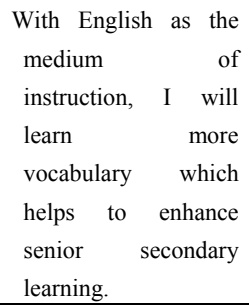 & $26 \%$ & $50 \%$ & $18 \%$ & $6 \%$ \\
\hline 5 & $\begin{array}{l}\text { With English as the } \\
\text { medium of instruction, } \\
\text { it slows down my } \\
\text { learning obviously. }\end{array}$ & $23 \%$ & $33 \%$ & $36 \%$ & $8 \%$ \\
\hline 6 & $\begin{array}{l}\text { With English as the } \\
\text { medium of instruction, } \\
\text { smaller impact is } \\
\text { observed over } \\
\text { Mathematics and } \\
\text { Science. }\end{array}$ & $15 \%$ & $38 \%$ & $33 \%$ & $14 \%$ \\
\hline 7 & $\begin{array}{l}\text { With English as the } \\
\text { medium of instruction, } \\
\text { learning progress and } \\
\text { effectiveness are more } \\
\text { affected. }\end{array}$ & $32 \%$ & $41 \%$ & $21 \%$ & $6 \%$ \\
\hline 8 & $\begin{array}{l}\text { With English as the } \\
\text { medium of instruction, } \\
\text { my academic results } \\
\text { can be maintained. }\end{array}$ & $8 \%$ & $29 \%$ & $45 \%$ & $18 \%$ \\
\hline 9 & $\begin{array}{l}\text { With English as the } \\
\text { medium of } \\
\text { instruction, my } \\
\text { academic results are } \\
\text { expected to } \\
\text { decline. }\end{array}$ & $26 \%$ & $35 \%$ & $30 \%$ & $9 \%$ \\
\hline
\end{tabular}

Table 2d. Students’ Attitudes

\begin{tabular}{|c|c|c|c|c|c|}
\hline & & $\begin{array}{c}\text { Strongly } \\
\text { agree }\end{array}$ & Agree & Disagree & $\begin{array}{l}\text { Strongly } \\
\text { disagree } \\
\end{array}$ \\
\hline 1 & $\begin{array}{l}\text { I prefer having } \\
\text { English as the } \\
\text { medium } \\
\text { instruction. }\end{array}$ & $11 \%$ & $25 \%$ & $36 \%$ & $28 \%$ \\
\hline 2 & $\begin{array}{l}\text { I prefer having } \\
\text { Chinese as the } \\
\text { medium } \\
\text { instruction. }\end{array}$ & $48 \%$ & $36 \%$ & $11 \%$ & $5 \%$ \\
\hline 3 & $\begin{array}{l}\text { I feel delighted when } \\
\text { transferred from } \\
\text { partial-EMI to EMI } \\
\text { class. }\end{array}$ & $20 \%$ & $28 \%$ & $34 \%$ & $18 \%$ \\
\hline 4 & $\begin{array}{l}\text { I feel depressed } \\
\text { when transferred } \\
\text { from partial-EMI to } \\
\text { EMI class. }\end{array}$ & $20 \%$ & $29 \%$ & $32 \%$ & $19 \%$ \\
\hline 5 & $\begin{array}{l}\text { With English as the } \\
\text { medium of } \\
\text { instruction, I feel } \\
\text { more motivated to } \\
\text { learn. }\end{array}$ & $10 \%$ & $26 \%$ & $43 \%$ & $21 \%$ \\
\hline 6 & $\begin{array}{l}\text { With Chinese as the } \\
\text { medium of } \\
\text { instruction, I feel } \\
\text { more motivated to } \\
\text { learn. }\end{array}$ & $38 \%$ & $43 \%$ & $15 \%$ & $4 \%$ \\
\hline 7 & $\begin{array}{l}\text { In my opinion, } \\
\text { partial-EMI students } \\
\text { and EMI students } \\
\text { have the same level } \\
\text { of learning ability. }\end{array}$ & $19 \%$ & $40 \%$ & $28 \%$ & $13 \%$ \\
\hline 8 & $\begin{array}{l}\text { In my opinion, EMI } \\
\text { students have more } \\
\text { confidence than } \\
\text { partial-EMI students. }\end{array}$ & $17 \%$ & $31 \%$ & $39 \%$ & $13 \%$ \\
\hline 9 & $\begin{array}{l}\text { In my opinion, EMI } \\
\text { students learn faster } \\
\text { than partial-EMI } \\
\text { students. }\end{array}$ & $14 \%$ & $24 \%$ & $46 \%$ & $16 \%$ \\
\hline 10 & $\begin{array}{l}\text { I have an impression } \\
\text { that EMI students } \\
\text { are superior to } \\
\text { partial-EMI } \\
\text { students. }\end{array}$ & $19 \%$ & $27 \%$ & $36 \%$ & $18 \%$ \\
\hline
\end{tabular}


Table 2e. Factors affecting MOI choice

\begin{tabular}{|c|c|c|c|c|c|}
\hline & & $\begin{array}{c}\text { Strongly } \\
\text { agree }\end{array}$ & Agree & Disagree & $\begin{array}{l}\text { Strongly } \\
\text { disagree }\end{array}$ \\
\hline 1 & $\begin{array}{l}\text { I mainly consider my } \\
\text { academic results when } \\
\text { choosing the medium of } \\
\text { instruction. }\end{array}$ & $36 \%$ & $51 \%$ & $12 \%$ & $1 \%$ \\
\hline 2 & $\begin{array}{l}\text { I mainly consider my } \\
\text { language ability when } \\
\text { choosing the medium of } \\
\text { instruction. }\end{array}$ & $37 \%$ & $50 \%$ & $12 \%$ & $1 \%$ \\
\hline 3 & $\begin{array}{l}\text { I mainly consider my } \\
\text { teachers' advice when } \\
\text { choosing the medium of } \\
\text { instruction. }\end{array}$ & $13 \%$ & $38 \%$ & $40 \%$ & $9 \%$ \\
\hline 4 & $\begin{array}{l}\text { I mainly consider my } \\
\text { parents' advice when } \\
\text { choosing the medium of } \\
\text { instruction. }\end{array}$ & $15 \%$ & $42 \%$ & $34 \%$ & $9 \%$ \\
\hline 5 & $\begin{array}{l}\text { I mainly consider my } \\
\text { friends' advice when } \\
\text { choosing the medium of } \\
\text { instruction. }\end{array}$ & $11 \%$ & $29 \%$ & $44 \%$ & $16 \%$ \\
\hline 6 & $\begin{array}{l}\text { I mainly consider the } \\
\text { university entry } \\
\text { requirement when } \\
\text { choosing the medium of } \\
\text { instruction. }\end{array}$ & $30 \%$ & $37 \%$ & $26 \%$ & $7 \%$ \\
\hline 7 & $\begin{array}{l}\text { I choose English as the } \\
\text { medium of instruction } \\
\text { mainly due to the fact } \\
\text { that English remains as } \\
\text { one of the main criteria } \\
\text { for university enrolment. }\end{array}$ & $28 \%$ & $42 \%$ & $21 \%$ & $9 \%$ \\
\hline 8 & $\begin{array}{l}\text { I choose English as the } \\
\text { medium of instruction } \\
\text { mainly due to the fact } \\
\text { that good English } \\
\text { proficiency helps me find } \\
\text { a job more easily. }\end{array}$ & $35 \%$ & $47 \%$ & $12 \%$ & $6 \%$ \\
\hline 9 & $\begin{array}{l}\text { I choose Chinese as the } \\
\text { medium of instruction } \\
\text { mainly due to the fact } \\
\text { that mother tongue helps } \\
\text { me to understand } \\
\text { content-based subject } \\
\text { knowledge better. }\end{array}$ & $40 \%$ & $42 \%$ & $14 \%$ & $4 \%$ \\
\hline 10 & $\begin{array}{l}\text { I choose Chinese as the } \\
\text { medium of instruction } \\
\text { mainly due to the fact } \\
\text { that mother tongue helps } \\
\text { to improve my academic } \\
\text { results. }\end{array}$ & $41 \%$ & $38 \%$ & $17 \%$ & $4 \%$ \\
\hline 11 & $\begin{array}{l}\text { I choose Chinese as the } \\
\text { medium of instruction } \\
\text { mainly due to the change } \\
\text { of medium of instruction } \\
\text { policy by the } \\
\text { government. }\end{array}$ & $39 \%$ & $38 \%$ & $18 \%$ & $5 \%$ \\
\hline
\end{tabular}

An independent t-test was run to compare the means of two groups of students (i.e. EMI classes vs partial-EMI classes) across the three participating schools on the scales of English proficiency, MOI effect on learning, EMI effect on students, students' attitudes, factors affecting MOI choice and one other scale that is not relevant to this paper.

The t-test results indicate that the two groups of students had significantly different views on most of the factors. The group mean difference of 'MOI effect on English proficiency' is significant with $\mathrm{t}=$ $2.3^{*}, \mathrm{p}<.05$. EMI students score a higher mean $(\mathrm{M}=3.02)$ than partial-EMI students $(\mathrm{M}=2.88)$. More EMI students than CMI students believed that EMI helped to enhance their English proficiency. The overall group mean difference of 'MOI effect on learning' is significant, $\mathrm{t}=3.98 * * *, \mathrm{p}<.001$. PartialEMI students have a higher mean (3.01) than EMI students (2.78). The significant difference shows that partial-EMI students were more affected by the new MOI policy than the EMI students, as further supported by the higher mean scores of partial-EMI students on the sub-factors 'mixed code' (2.90) and 'strategies' (2.97) over EMI students (2.55 on 'mixed code' and 2.79 on 'strategies'). These show that compared with the EMI group, partial-EMI students preferred teachers using mixed code more and they had to employ more strategies when learning through English. Concerning the factor of 'EMI effect on students', there is a significant difference in views between the EMI group and partial-EMI group $(\mathrm{t}=$ $\left.4.25^{* * *}, \mathrm{p}<.001\right)$. The overall mean score of both groups on this factor is lower than that of some other factors (EMI group=2.39; partial-EMI group=2.15). The same is true with the sub-factors of 'EMI enhancing learning' (EMI group=2.21; partial-EMI group $=1.97$ ) and 'improve academic results' (EMI group $=2.71$; partial-EMI group=2.53). These show that they were less positive about the impact of EMI on their academic results although the EMI group tended to be more optimistic than the partial-EMI group. The overall group mean difference of 'students' attitudes' is significant with $\mathrm{t}=-5.20 * * *$, $\mathrm{p}<.001$. The sub-factor of 'positive attitude towards EMI' is also significant with $\mathrm{t}=-6.15^{* * *}, \mathrm{p}<.001$ but the other sub-factor of 'sense of superiority of being in EMI class' is not significant with $\mathrm{t}=-2.4, \mathrm{p}<.001$. As the overall mean score of both groups on this factor is lower than that of some other factors (EMI group=2.43; partial-EMI group=2.09), it reflects that both EMI and partial-EMI students tended not to prefer EMI although their views were significantly different. On the contrary, both groups shared a similar view that students in the EMI class did not necessarily have a sense of superiority over their counterparts in the CMI class. Concerning the subfactors affecting students'choice of MOI, three out of five factors have significant group difference: 'future study and job requirement' with $\mathrm{t}=-3.67 * * *$; 'possibility to achieve higher grades' with $\mathrm{t}=5.00 * * *$; 
'academic ability and results' with $\mathrm{t}=2.74 * *$. The mean scores of these sub-factors for both groups are well above 2.5, so both EMI and partial-EMI students agreed that 'future study and job requirement', 'possibility to achieve higher grades' and 'academic ability and results' were the factors they considered when choosing MOI although their views were significantly different.

Table 3: t-test comparison results between EMI students and partial-EMI students on various scales

\begin{tabular}{|c|c|c|c|c|}
\hline & \multicolumn{2}{|c|}{$\begin{array}{l}\text { partial-EMI } \\
\text { students (from } \\
\text { school 123) }\end{array}$} & \multicolumn{2}{|c|}{$\begin{array}{c}\text { EMI students } \\
\text { (from school 123) }\end{array}$} \\
\hline & M & (s.d.) & $\mathrm{M}$ & (s.d.) \\
\hline \multirow{5}{*}{$\begin{array}{l}\text { MOI effect on English Proficiency } \\
\text { MOI effect on learning } \\
\text { - mixed code } \\
\text { - difficulties } \\
\text { - strategies }\end{array}$} & 2.88 & $(.61)$ & 3.02 & $(.57)$ \\
\hline & 3.01 & $(.51)$ & 2.78 & $(.59)$ \\
\hline & 2.90 & (.69) & 2.55 & $(.76)$ \\
\hline & 3.15 & $(.73)$ & 3.03 & $(.77)$ \\
\hline & 2.97 & (.64) & 2.79 & (.69) \\
\hline EMI effect on students & 2.15 & $(.56)$ & 2.39 & $(.56)$ \\
\hline \multirow{2}{*}{$\begin{array}{l}\text { - enhance learning } \\
\text { - improve academic results }\end{array}$} & 1.97 & $(.65)$ & 2.21 & (.67) \\
\hline & 2.53 & (.69) & 2.71 & (.61) \\
\hline Students' attitudes & 2.09 & (.64) & 2.43 & (.65) \\
\hline - positive attitudes & 1.97 & $(.70)$ & 2.42 & $(.75)$ \\
\hline \multirow{2}{*}{\multicolumn{5}{|c|}{$\begin{array}{l}\text { - sense of superiority } \\
\text { Factors affecting MOI choice }\end{array}$}} \\
\hline & & & & \\
\hline \multicolumn{5}{|l|}{ - Others' suggestions } \\
\hline \multirow{2}{*}{$\begin{array}{l}\text { - Future study and job requirement } \\
\text { - Possibility to achieve higher grades }\end{array}$} & 2.89 & (.78) & 3.17 & $(.70)$ \\
\hline & 3.29 & (.71) & 2.84 & $(.90)$ \\
\hline \multirow{2}{*}{$\begin{array}{l}\text { - Possibility to achieve higher grades } \\
\text { - Academic ability and results }\end{array}$} & 3.28 & (.63) & 3.11 & $(.56)$ \\
\hline & 3.14 & $(.85)$ & 3.00 & $(.92)$ \\
\hline Impact of MOI policy on schools & 2.84 & $(.53)$ & 2.83 & $(.62)$ \\
\hline \multirow{2}{*}{$\begin{array}{l}\text { - flexibility to promote English } \\
\text { - special arrangements }\end{array}$} & 3.14 & $(.61)$ & 3.21 & $(.65)$ \\
\hline & 2.57 & (.73) & 2.51 & $(.87)$ \\
\hline$\# \mathrm{p}=.05$ & ${ }^{*} \mathrm{p}<.01$ & & & \\
\hline
\end{tabular}

Table 4. Regression results on EMI students by various scales

\begin{tabular}{|c|c|c|}
\hline Variables & $\begin{array}{c}\text { Standardized } \\
\beta \\
\text { Schoo }\end{array}$ & $\begin{array}{l}\text { t-value } \\
123\end{array}$ \\
\hline d-gender & -.15 & $-2.72 * *$ \\
\hline Age & -.18 & $-3.28 * * *$ \\
\hline English Proficiency & -.07 & -.84 \\
\hline \multicolumn{3}{|l|}{ MOI effect on learning } \\
\hline - mixed code & -.09 & -1.06 \\
\hline - difficulties & .60 & .89 \\
\hline - strategies & -.12 & $-2.08^{*}$ \\
\hline \multicolumn{3}{|l|}{ EMI effects on students } \\
\hline \multirow{2}{*}{ - enhance learning } & -.15 & -1.68 \\
\hline & -.04 & -.05 \\
\hline \multicolumn{3}{|l|}{ Students' attitudes } \\
\hline - positive attitudes & .20 & $2.07 *$ \\
\hline \multirow{2}{*}{\multicolumn{3}{|c|}{$\begin{array}{l}\text { - sense of superiority } \\
\text { Factors affecting MOI choice }\end{array}$}} \\
\hline & & \\
\hline - Others' suggestions & -.12 & $-2.18^{*}$ \\
\hline - Future study and job requirement & .18 & $2.78^{* *}$ \\
\hline - Possibility to achieve higher grades & -.18 & $-2.42 *$ \\
\hline - Academic ability and results & -.08 & -1.38 \\
\hline \multirow{2}{*}{$\begin{array}{l}\text { - Government policy } \\
\text { Impact of MOI policy }\end{array}$} & .00 & .03 \\
\hline & & \\
\hline \multirow{2}{*}{$\begin{array}{l}\text { - flexibility to promote English } \\
\text { - special arrangements }\end{array}$} & .04 & .71 \\
\hline & .01 & .12 \\
\hline $\mathrm{R}^{2}$ & & .22 \\
\hline F-value & & $4.69^{* * *}$ \\
\hline${ }^{*} * \mathrm{p}<.01$ & $* * * \mathrm{p}<.001$ & \\
\hline
\end{tabular}

Multiple regressions show that MOI has an impact on learning and teaching in general, and on students specifically. The changing MOI was found to have affected their learning effectiveness, e.g. learning not as fast as before; therefore, both the teacher and the students had to apply different strategies to enhance learning effectiveness, such as using mixed code. Compared with the EMI group, partial-EMI students experienced more difficulties. As for the sub-factor of attitude pertaining to students' sense of superiority about being placed in an EMI class, the regression result is not significant $(\mathrm{t}$-value=-.71). In addition, the impact of the new medium of instruction policy on students' English proficiency is not significant ( $\mathrm{t}$-value $=-.84)$.

Below is a summary of the findings:

1. The majority of students did not seem to favour the use of EMI.

2. Students in the EMI classes had a much more positive attitude than students in the partial-EMI classes towards the changing medium of learning from Chinese to English.

3. Approximately half of the students claimed that they would feel delighted if they were transferred from the partial-EMI class to EMI class.

4. Approximately half of the students claimed that they would feel depressed if they were transferred from the EMI class to partial-EMI class.

5. The changing MOI policy had a significant impact on students' learning.

6. Students from both EMI and partial-EMI classes admitted that they generally faced lots of difficulties when learning through the English medium.

7. EMI students were able to cope with the difficulties in a more proactive way than partialEMI students.

8. The majority of students expected teachers to use more mixed code in teaching.

9. The impact of the changing MOI policy on the enhancement of English proficiency was not significant.

10. More than half of the students believed that EMI and partial-EMI students had the same level of learning ability, and that EMI students were not superior to partial-EMI students.

11. Five factors affecting students MOI preference were identified: 'others' suggestions', 'study and job requirement', 'possibility to achieve higher grades', 'academic performance' and 'government's policy'.

\section{Discussion}

The first research question pertains to students' attitudes towards the changing MOI from Chinese to English. Finding 1 deriving from both the descriptive 
statistics and t-test indicates that the majority of the students participating in the study did not seem to favour the use of EMI. This finding is congruent with another finding that the students generally faced lots of difficulties when learning through the English medium (Finding 6), for example, a large number of vocabulary and complicated sentences that block the understanding of content-based subject knowledge. However, Findings 3 and 4 seem to contradict Finding 1 as approximately half of the students claimed that they would feel delighted if they were transferred from the partial-EMI class to EMI class (Findings 3) whereas approximately half of the students claimed that they would feel depressed if they were transferred from the EMI class to partialEMI class (Findings 4). The participants had just entered Secondary 1 when the survey was conducted. They were in the transition period of adapting to English-medium learning because nearly all primary schools in Hong Kong use Chinese as the teaching medium. Inevitably they found learning through English difficult, and thus the majority was reflecting their genuine feeling that they did not like EMI. And yet deep down in their hearts students know very well that English is a key to success in Hong Kong [1], [14], [17], as Li remarks, "This self-awareness is deep in the psyche of Hong Kong Chinese, a psyche which transcends boundaries across generations and socio-economic classes" [9]. Therefore, the EMI class, a higher-ability group than the partial-EMI class, was more proactive and strived hard to cope with the difficulties in learning through English (Finding 7). They strongly believed that some hurdles if overcome (e.g. the large number of English vocabulary learnt in content-based subjects) would facilitate their learning in senior forms.

On the whole, the survey shows that students in the EMI classes had a much more positive attitude than students in the partial-EMI classes towards the changing medium of learning from Chinese to English (Finding 2). Apart from their attitudes towards EMI, how do students in the EMI classes view their counterparts in the CMI classes within the same school? Contrary to the public's expectation, more than half of the students in the present study believed that EMI and partial-EMI students had the same level of learning ability, and that EMI students were not superior to partial-EMI students (Finding 9). This is corroborated by the insignificant result of the multiple regression test ( $\mathrm{t}-\mathrm{value}=-.71$ ). This may be due to the fact that the three sample schools are not high banding schools and students tend to be more humble. Unlike before, under the compulsory Chinese medium-of-instruction policy schools were segregated into a minority of EMI schools, which were Band 1 schools (i.e. high band), and a majority of CMI schools, which were Band 2 and 3 schools (Band 3 being the lowest band). That is why the finetuning MOI policy is more flexible and equitable, providing students especially Band 2 and 3 students with more opportunities to learn through EMI.

The second research question is about how the changing MOI affects students' learning. Finding 5 shows that the changing MOI policy has a significant impact on students' learning. Basically the participating students encountered a lot of difficulties as mentioned previously (Finding 6). The majority of students expected teachers to use more mixed code in class (Finding 8), particularly the partial-EMI group. Using mixed code has been a common practice in lessons taught through the medium of English since the 1980s as reported in the Education Commission Report No. 1: the distinction of language use in the classroom "became blurred with the expansion of universal junior secondary education and both languages are, in fact, being used in varying degrees in different types of schools" [3]. This is a common finding in a number of studies conducted in various periods under different MOI policies in the past 30 years [6]; [7]; [13]; [16], [17]. The main reason for adopting mixed code is due to students' limited English proficiency. More than $80 \%$ of the students surveyed admitted that they needed to employ specific strategies in order to cope with learning through EMI, for example, preparing the lessons before attending classes, using the dictionary, forming study groups, attending tutorial classes, etc. The partial-EMI group had a significantly more pressing need for applying strategies in learning through English than the EMI group, as indicated in the $\mathrm{t}$-value $=2.57^{*}, \mathrm{p}<.05$, and their mean scores (the partial-EMI group: 2.97; the EMI group: 2.79).

Using mixed code in teaching is a controversial issue. On the one hand the supporters find it agreeable to use mixed code to teach content-based subjects because it facilitates higher order thinking and students find it easier to understand the concepts and subject knowledge taught in some Chinese words [8]; [19]. On the other hand, some scholars argue that mixed code can at most be used as a temporary measure [10]; otherwise, language development might be affected [17]. As for the effect of EMI on students specifically, the EMI and partialEMI groups had significantly different views. The mean score of the two groups on the sub-factors of whether EMI enhances learning and improves academic results tends to be on the lower end. As mentioned previously, the study was conducted at the initial stage of implementation, during which students encountered lots of difficulties and were trying to adapt to the new medium of learning. It is, therefore, too early for students to see any positive effect of EMI on learning.

The third research question concerns whether the fine-tuning MOI policy will enhance students' English proficiency. The mean score of both the EMI and partial-EMI groups tends towards the higher end of the scale. $70 \%$ of the respondents believed that 
EMI could help to enhance their English proficiency because the fine-tuning MOI policy allows more exposure to English. The result of the t-test $(\mathrm{t}-$ value $\left.=-2.3^{*},<.05\right)$ shows that the views of the two groups are significantly different. The EMI group was much more confident than the partial-EMI group that their English proficiency had been enhanced as they used English as a medium of learning in most subjects whereas partial-EMI students had a significantly different view. Nevertheless, the multiple regression test result ( $\mathrm{t}$-value $=-.84$ ) indicates that the impact of the fine-tuning MOI policy on English proficiency is not significant (Finding 9). One possible explanation for this is that the study was carried out in the first year of implementation of the new MOI policy, and the effect was not yet felt.

The last research question is related to the factors affecting students' choice of MOI. Five factors are identified based on the results of Pearson's factor analysis: 'others' suggestions', 'future study and job requirement', 'possibility to achieve higher grades', 'academic ability and results' and 'government's policy'. The EMI group and partial-EMI group had significantly different views on three of these factors according to the t-test result. The EMI group rated the factor 'future study and job requirement' more highly than the partial-EMI group, probably because EMI students generally have higher aspiration about their future, and entering university is their goal in life. On the other hand, the partial-EMI group rated 'academic ability and results' and 'possibility to achieve higher grades' more highly. Partial-EMI students are aware that in reality students with higher academic ability and better results stand better chances of being admitted to EMI classes. CMI enables them to understand the lessons better and increase the possibility to achieve higher grades.

After all, students are realistic and the choices they consider in selecting their medium of learning are rational ones. They realize the importance of English in Hong Kong, especially regarding climbing up the social hierarchy - i.e. entering university in order to find a good job - because good English is a stepping stone to success and it is a dominant social value in Hong Kong. Tsang's longitudinal study reveals that CMI students' chance of entering university was reduced by half as compared with EMI students [21]. 5. Conclusion and Recommendations

In summary, I have reported some preliminary findings of a study conducted in the first year of implementation of the fine-tuning medium-ofinstruction policy during 2010-2011. 461 Secondary 1 students from three schools were surveyed. Five relevant factors are identified and categorized as: English proficiency, MOI effects on learning, EMI effects on students, students' attitudes and factors affecting students' MOI choice. Altogether 11 findings are drawn from the analysis of the data. The majority of students did not seem to favour the use of
EMI, and yet some other findings indicate that at least half of them preferred being placed in EMI classes. The changing MOI policy had a significant impact on students' learning. They admitted encountering a lot of difficulties with EMI as they were in the transition period of shifting their medium of learning from Chinese to English. Comparatively, EMI students were able to cope with the difficulties in a more proactive manner than partial-EMI students. The labelling effect of the fine-tuning MOI policy on students is not as obvious as expected.

The fine-tuning MOI policy is an innovative policy which provides a flexible terrain for schools to offer different types of classes that cater for the needs of students with different language abilities. Under the new policy Band 2 and Band 3 schools, which were labelled as CMI schools under the previous compulsory Chinese medium-of-instruction policy, now have an opportunity to offer Englishmedium instruction to some students who are English-capable. Resolving the problem of mismatch between students' English ability and their medium of learning is, in fact, one of the strengths of the finetuning MOI policy. English-medium education signifies a promise to a brighter future, and students especially those in EMI classes are willing to strive hard to excel. An additional strength of the new policy is to provide students with a richer English environment at school. Formerly students in CMI schools were able to practise English skills in their English language lessons only. Now they are given the opportunities to use English to learn other content-based subjects. Hopefully, their English will be enhanced.

To conclude, English has become a global language and students, whether they like it or not, need to master this important tool; otherwise, they will be missed out in the era of globalisation. Hong Kong, an international financial centre hailed by Time Magazine as Ny.Lon.Kong (i.e. New York, London and Hong Kong) [5], January 28), is in great demand for proficient English speakers. Unfortunately the English standards of students in Hong Kong have been repeatedly reported to be declining since the early 1980s [3], [4]. The public perception of the English decline is supported by research findings, for example, "the results of this study are consistent with general anecdotal and research evidence suggesting that the English proficiency of Hong Kong undergraduates is low" [20]. The English decline reached an alarming proportion when the English Proficiency Index (EPI) was released by Education First (EF) in 2012. Hong Kong ranked 25th (EPI: 53.65) among 54 countries in 2012, and 12th (EPI: 54.44) among 44 countries in 2011. Hong Kong cannot afford to see the further dip of English. The fine-tuning MOI policy, if well implemented, is able to raise the English standards because Content and Language Integrated Learning (CLIL) is a way out. Collaborative teaching between 
content-based subject teachers and language teachers is recommended.

\section{References}

[1] M. Axler, A. Yang and T. Stevens, 'Current language attitudes of Hong Kong Chinese adolescents and young adults', in M. C. Pennington, ed., Language in Hong Kong at century's end, Hong Kong University Press, Hong Kong, 1998, pp. 329-338.

[2] Census and Statistics Department, Hong Kong 2011 population census summary results, Government Printer, Hong Kong, 2011.

[3] Education Commission, Education Commission Report No. 1, Government Printer, Hong Kong, 1984.

[4] Education Commission, Education Commission Report No. 4, Government Printer, Hong Kong, 1990.

[5] Elliott, M. (2008, January 28). A tale of three cities. Time, 30-33.

[6] S. Evans and C. Green, 'Why EAP is necessary: a survey of Hong Kong tertiary students', Journal of English for Academic Purposes, 6, 3-17, 2007.

[7] J. P. Gibbons, 'Attitudes towards languages and codemixing in Hong Kong', Journal of Multilingual and Multicultural Development, 4(2\&3), 129-147, 1983.

[8] D. C. S. Li, 'The plight of the purist', in M. C. Pennington, ed., Language in Hong Kong at century's end Hong Kong University Press, Hong Kong, 1998, pp. 161189 .

[9] D. Li, 'Hong Kong parents' preference for Englishmedium education: passive victims of imperialism or active agents of pragmatism?', in A. Kirkpatrick, ed, Englishes in Asia: Communication, identity, power \& education, Language Australia, Melbourne, 2002, pp. 29-62.

[10] A. M. Y. Lin, 'Deconstructing "mixed code"', in D. C. S. Li, A. M. Y. Lin and W. K. Tsang, eds., Language and education in postcolonial Hong Kong, Linguistic Society of Hong Kong, Hong Kong, 2000, pp. 179-194.

[11] W. W. M. Low and D. Lu, 'Persistent use of mixed code: An exploration of its functions in Hong Kong schools', International Journal of Bilingual Education and Bilingualism, 2006, 9(2), pp. 181-204.

[12] D. F. P. Ng, 'Medium and learning in Chinese and English in Hong Kong classrooms', Language Policy, 2007, 6, pp. 163-183.

[13] M.C. Pennington, 'Pattern and variation in use of two languages in the Hong Kong secondary English class', RELC Journal, 1995, 26 (2), pp. 80-105.

[14] A.Y.K. Poon, 'Bilingualism and monolingualism: A shift in Hong Kong government's language-in-education policy', in V. Berry and A. McNeill, ed., Policy and practice in language education, Department of Curriculum Studies, The University of Hong Kong, Hong Kong, 1998,pp. 89-104. [15] A.Y.K., Poon, 'Impact of Chinese medium instruction policy on English language learning in post-1997 Hong Kong', International Journal of Bilingual Education and Bilingualism, 1999, 2 (2), pp. 131-146.

[16] A.Y.K., Poon, Medium of instruction in Hong Kong: Policy and Practice, UPA, Lanham, 2000.

[17] A.Y.K., Poon, 'Reforming medium of instruction in Hong Kong', in C. Ng and P. Renshaw, ed., Reforming Learning: Issues, Concepts and Practice in the AsianPacific Region, Springer, Dordrecht, 2009, pp. 199-232.

[18] D.W.C., So, 'Implementing mother-tongue education amidst societal transition from diglossia to triglossia in Hong Kong', Language and Education, 1989, 3(1), 29-44.
[19] D.W.C., So, 'Language-based bifurcation of secondary schools in Hong Kong: Past, present \& future', in K.K. Luke, ed., Into the twenty-first century: Issues of language in education in Hong Kong, Linguistic Society of Hong Kong, Hong Kong, 1998, pp. 69-95.

[20] R. Stone, 'English in Hong Kong: Word knowledge skills of science undergraduates', Hong Kong Journal of Applied Linguistics, 1994, 4(2), 93-100.

[21] W.K. Tsang, The effect of medium-of-instruction policy on education advancement, The Chinese University of Hong Kong, Hong Kong, 2008.

[22] S. K. Tse, M. Shum, W. W. Ki and Y. M. Chan, 'The medium dilemma for Hong Kong secondary schools', Language Policy, 6(1), 2007, pp. 135-162.

[23] S. K. Tse, M. Shum, W. W. Ki and C. P. C. Wong, 'The transition from English to mother-tongue Chinese as medium of instruction', L1-Educational Studies in Language and Literature, 1, 2001, pp. 9-36.

[24] P. Tung, R. Lam and W. K. Tsang, 'English as a medium of instruction in post-1997 Hong Kong: What students, teachers', 1997, 28(4), pp. 441-459.

[25] D.Y. Yip, D. Coyle, and W.K. Tsang, 'Evaluation of the effects of the medium of instruction on science learning of Hong Kong secondary students: Instructional activities in science lessons', Education Journal, 35(2), 78-107, 2007. 